\title{
Väestöliiton kansanterveystoimiston työmuodoista ja niiden kehityksestä.
}

\section{Aarno Turunen}

Länsimaisen kulttuurin piiriin kuuluvassa maailmassa on viimeisten vuosikymmenien aikana tapahtunut nopeaa ja ratkaiseviin tuloksiin johtanutta kehitystä lääketieteen ja terveydenhoidon alalla. Lääketieteellisen tutkimustyön saavuttamat voitot näkyvät selvimpinä pikkulasten kuolleisuutta osoittavien lukujen alenemisena, infektiotautien aiheuttamien kuolemantapausten ja työpäivämenetysten vähenemisenä sekä välillisesti edellisistä johtuvana ihmisen keski-iän pitenemisenä. Nykyaikaisessa yhteiskunnassa elävä ihminen on lääketieteen ja terveydenhoidon kehityksen turvin jo syntymästään saakka varustettu terveempään ja pitempään elämään kuin vuosisatamme ensimmäisinä vuosikymmeninä.

Rinnan tämän ilahduttavan terveydenhoidollisen kehityksen kanssa on länsimaisessa yhteiskuntajärjestyksessä samalla tapahtunut syvällisiä muutoksia, joiden vaikutukset terveen yhteiskunnan ja yksilön kannalta katsoen eivät ole pelkästään myönteisiä. Yhä lisääntyvä teollistuminen ja kaupunkilaistuminen sekä naisen yhteiskunnallisen aseman täydellinen muuttuminen, joka parhaiten ilmenee naisen hakeutumisessa työhön kodin ulkopuolelle, ovat johtaneet yhteiskunnan peruskiven, perheen aseman heikentymiseen ja horjumiseen ja saattaneet samalla perheen piiriin kuuluvat yksilöt suuriin sosiaalisiin sopeutumisvaikeuksiin ja ristiriitoihin yhteiskunnassa. Tästä ovat taas seurauksena monet väestöpoliittisesti kielteiset ilmiöt, joista mainittakoon avioliiton solmiamisiän kohoaminen, avioerojen lisääntyminen ja raskaudenkeskeytysten määrän nousu syntyväisyyden laskiessa. Yhteiskun- 
nallinen kehitys ja sosiaalipoliittinen suuntaus ovat näin ollen olleet omiaan vahvasti vastustamaan sitä suotuisaa yksilön ja perhe-elämän kehitystä, jolle tehostunut terveydenhoitotyö on luonut edellytykset. Monet tutkijat ovatkin pyrkineet teoreettisesti selvittämään näiden kahden, lääketieteellisen ja yhteiskunnallisen tekijän taistelua ja eräät ovat tulleet varsin pessimistisiin lopputuloksiin. Kirjassaan »Suicide of Mankind» Teupken sanoo: 》Järkyttäessään keinotekoisesti ikivanhaa syntymän ja kuoleman tasapainoa, ihmiskunta tulee tekemään itsemurhan. Maailman väestön suunnaton lisääntyminen tulee aiheuttamaan paitsi uhkaavaa nälkäkuolemaa, niin paljon yhteiskunnallisia epäkohtia, että ihmiskunta ajautuu tuhoon psyykisten ja fyysisten voimavarojen puutteessa.» Sotaa seurannut aikakausi, jota me vieläkin elämme, on lisäksi kärjistänyt yhteiskunnallisia olosuhteita epäedulliseen suuntaan. Epävakaiset talousolot, asunnonpuute ja lisääntynyt kilpailu kaikilla elämän aloilla, ovat vaikuttaneet haitallisesti avioliiton solmiamiseen ja perheen muodostumiseen, täten horjuttaen yhteiskuntamme perustaa.

Maissa, joissa yhteiskunnan teollistaminen on kehittynyt pisimmälle, kuten Yhdysvalloissa ja Englannissa, on jo 30-luvulla ryhdytty aktiivisesti taistelemaan näitä yhteiskunnallisen kehityksen aiheuttamia epäkohtia vastaan. Väestön kasvun ja sen laadullisen parantamisen turvaamiseksi syntyi näissä maissa, alunperin yksityisten kansalaisjärjestöjen aloitteista, väestöpoliittinen ajattelutapa, johon perustuen luotiin perheen turvaksi laaja sosiaalipoliittinen lainsäädäntö. Samalla syntyi erikoinen lääketieteen haara, sosiaalinen lääketiede, tutkimaan nykyaikaisessa yhteiskunnassa esiintyviä, yksilöön haitallisesti vaikuttavia tekijöitä ja etsimään parannuskeinoja niihin. Lisäksi perustettiin Yhdysvalloissa ja Englannissa lääkärien aloitteesta yksityisiä järjestöjä, jotka koko maata käsittävässä neuvonta- ja valistustoiminnassaan ovat pyrkineet perheellisten aseman lujittamiseen ja yksilön sosiaalisen turvallisuuden lisäämiseen. Rikollisten raskaudenkeskeytysten vähentämiseksi ja sosiaalisen kurjuuden lieventämiseksi ovat nämä järjestöt voimakkaasti korostaneet järkipe- 
räisen lapsirajoituksen välttämättömyyttä nykyaikaisessa yhteiskunnassa, ja luoneet laajan, avioliiton terveydenhoidollisia ongelmia käsittelevän neuvolaverkoston maihinsa.

Meillä Suomessa on yhteiskunnallinen kehitýs pienemmässä mittakaavassa johtanut samaan suuntaan ja sen aiheuttamat varjopuolet ovat olleet selvästi nähtävissä jo ennen viimeisiä sotiamme. Lukuisista, perheen asemaa turvaavista lainsäädännöllisistä toimenpiteistä ja erilaisista avustuksista huolimatta, joiden avulla valtiovalta pyrki helpottamaan kodinperustamiskustannuksia, tasaamaan perhekustannuksia ja suomaan jokaiselle odottavalle äidille vapaan äitiyshuollon, äitiysavustuksen ja synnytyslomaa, ei näillä toimenpiteillä pystytty aiheuttamaan käännettä jo syntyneessä yhteiskunnallisesti epäsuotuisassa kehityksessä. Lääkärit ja sosiaalisesti valistuneet yksilöt kiinnittivät meillä vakavaa huomiota suhteettoman korkeaan rikollisten raskaudenkeskeytysten lukumäärään, suureen lapsettomien avioliittojen lukuun sekä lisääntyvään avioerojen määrään. Näissä-piireissä oivallettiin pian, ettei pelkin lainsäädännöllisin toimenpitein voida saada aikaan parannusta, vaan että näiden epäkohtien korjaaminen vaatii yksilöön kohdistuvaa, henkilökohtaista valistusta ja ohjausta.

Väestöliiton piirissä heräsi ajatus saada kootuksi avioliitossa ilmenevien terveydellisten häiriöiden ja vaikeuksien tutkimus ja hoito samassa pisteessä toimivien asiantuntijoiden käsiin, ja näin oli luotu pohja ensimmäisen avioliittoneuvolan syntymiselle maassamme. Maallemme ominaiset, mentaliteettiin, uskontoon ja taloudelliseen asemaan liittyvät näkökohdat pakoittivat neuvolan suunnittelussa kuitenkin poikkeamaan ulkomaisista esikuvista ja pyrkimään monissa suhteissa omaperäisiin ratkaisuihin. Ennen kaikkea on avioliittoneuvolatyössä Väestöliiton taholta haluttu joka suhteessa korostaa avioliittoon kytkeytyvien eetillis-moraalisten arvojen merkitystä.

Neuvontaa aloitettaessa oli tarkoituksena kiinnittää erikoista huomiota avioliittoon aikovien ohjaukseen ja terveydelliseen tarkastukseen. Aikana, jolloin siveellinen vastuuntunto yleensä oli alentunut, katsottiin avioliittoon aikovien lääkärintarkastuksen 
olevan omiaan sitä lisäämään. Myöskin jo puhtaasti eugeenisistä syistä, kansakunnan jälkikasvun kannalta, on tätä tarkastusta pidettävä tarpeellisena. Nykyisinhän vaaditaan avioliittoon aikovilta vain kirjallinen vakuutus siitä, etteivät he sairasta tarttuvassa vaiheessa olevaa sukupuolitautia tai perinnöllistä kaatumatautia, mutta käytännössä ei tällä vaatimuksella valitettavasti ole juuri mitään merkitystä. Lääkärintarkastusta avioliittoon aikoville käytäntöön sovellettaessa nousevat jälkeläisten laatua ja aviopuolisoiden avioliittoon sopeutuvaisuutta koskevat kysymykset kokonaan toiselle tasolle. Kuluvan vuoden aikana on tähän neuvontaan yhteistoiminnassa Yliopiston perinnöllisyystieteellisen laitoksen kanssa päätetty liittää erikoinen, ihmisen perinnöllisyyskysymyksiå käsittelevä neuvontamuoto nk. perinnöllisyysneuvonta, jonka avulla pyritään, paitsi ratkaisemaan käytännöllisiä ongelmia, myöskin luomaan perustaa humaanigeneettiselle tutkimustyölle maassamme.

Toisena avioliittoneuvonnan päätarkoituksena oli kiinnittää huomiota avioliitossa olevien järkiperäiseen syntyvyydensäännöstelyn ohjaukseen. Väestöliiton kantaan ryhtyä syntyvyydensäännöstelyn esitaistelijaksi vaikutti ratkaisevasti synkkä aborttitilanne maassamme. Kaksi kolmasosaa rikollisista raskaudenkeskeytyksistä suoritetaan naimisissa oleville naisille. Abortin tekeminen on vähitellen yhteiskunnassamme tullut ikäänkuin hyväksytyksi lapsirajoituksen normaalimenetelmäksi. Parikymmentätuhatta rikollista aborttia vuosittain ei ole kunniaksi näin pienelle kansalle eikä sen sosiaalipolitiikalle. Rikollisten aborttien pääsyynä ollaan taipuvaisia pitämään sosiaalisia oloja ja yhteiskunnallisilla uudistuksilla voidaankin ehkä niiden torjunnassa saada osittaista parannusta aikaan. Naapurimaassamme Ruotsissa on tämä sosiaalinen, abortteja ehkäisevä toiminta kehitetty huippuunsa: Elintaso on korkea ja lisäksi on siellä esimerkillisesti järjestetty äitiyshuolto, vapaa synnytyshoito, lastenhoitokeskukset jne. ja kuitenkin on Ruotsissa rikollisten raskaudenkeskeytysten lukumäärä samaa suuruusluokkaa kuin meillä. Pahin sosiaalinen epäkohta, joka merkitsee enemmän kuin kaikki ne ulkoiset tekijät, 
joita uudistuksilla ja avustuksilla yritetään poistaa, on kuitenkin väärään suuntaan kehittynyt elämänkatsomus. Elämän tarkoituksena pidetään onnen saavuttamista niin nopeasti ja vähällä vaivalla kuin mahdollista ja onni on nykyisen elämänkatsomuksen mukaan korkea elintaso. Tämän päämäärän saavuttamiseksi on sekä miehen että vaimon oltava ansiotyössä. Lapsen syntyminen tällaiseen perheeseen tietää vaimon ansioiden keskeytymistä vähintäin $1-2$ vuoden ajaksi ja elintason madaltumista. Tällöin ollaan valmiit usein uhraamaan kehittymässä oleva ihmistaimi hyvinvoinnin ja mukavuuden alttarille. Luonnollisesti on myöskin lukuisia tapauksia, joissa elintaso ennestään on jo niin matala, että useamman jälkeläisen elättäminen aiheuttaa todellista kurjuutta taikka tapauksia, jolloin vaimon sairaalloisuus ja ylirasittuneisuus ei tahdo kestää tiheästi uusiutuvia raskauksia. Tällöin on ongelman tausta toinen, mutta sen ratkaiseminen on mahdollista vain samoin menetelmin kuin ensin mainitussakin tapauksessa. Ennenkuin perhekasvatuksen ja yleisen valistustoiminnan avulla saadaan yhteiskunnassamme kasvatettua sukupolvi, joka osaa arvostaa terveen ja elinkelpoisen perheen todellista onnea tuovan merkityksen ja joka omaa seksuaalista vastuuntuntoa, ei meillä ole aborttikysymyksen ratkaisemiseksi muuta mahdollisutta kuin se, että sekä avioliitossa olevat että myös aviottomat sterilisoivat· yhdyselämänsä varmoilla ehkäisykeinoilla, mikäli molemmat asianosaiset eivät ole yksimielisiä siitä, että he saattavat maailmaan lapsen, jota he myöskin huoltavat.

Syntyvyyden säännöstelyn toisena tärkeänä tarkoituksena on vapauttaa aviovaimo alituisen raskaudenpelon aiheutamasta henkisestä rasituksesta. Onhan selvää, että monikaan nainen ei voi terveenä pysyen synnyttää lapsia jatkuvasti vuoden-kahden väliajoin. Mikäli näin tapahtuu, on seurauksena useinkin avioelämän rikkoutuminen ja perhe-elämän ristiriidat, jotka johtuvat naisen torjuvasta suhtautumisesta seksuaalielämään. Synnytysten välillä on vaimon saatava lepoaika vapaana raskaaksitulemisen pelosta. Jo puhtaasti lääketieteelliset syyt pakoittavat säännöstelemään lapsien liian tiheää syntymistä. On todettu, että jos lapsen syn- 
tymisen väliaika perheessä on liian lyhyt, niin näitä lapsia kuolee ensimmäisinä ikävuosinaan paljon enemmän kuin lapsia, jotka ovat syntyneet pitemmin väliajoin. Kokemus osoittaa, ettei nykyaikaisin ehkäisymenetelmin suoritettu syntyvyyden säännöstely uhkaa kansan väkiluvun lisääntymistä, vaan pahimpana uhkana siihen ovat raskauden pelko sekä väärään ja epäinhimilliseen raskaudenkeskeytykseen perustuva lapsirajoitus.

Yhdessä avioliittoon aikovien ja syntyvyydensäännöstelyohjausta hakevien potilaiden kanssa alkoi avioliittoneuvoloihin saapua enenevässä määrin raskaudentilassa olevia, jotka neuvolan kautta halusivat anoa raskaudenkeskeyttämistä. Suurimmalla osalla näistä potilaista oli keskeytyspyyntönsä perustana sosiaaliset syyt; asuntopula, miehen alkoholismi tai huono taloudellinen asema. Näiden potilaiden menestyksellinen hoitaminen vaati huomattavasti suurempaa asiantuntemusta ja paljon enemmän aikaa kuin mitä avioliittoneuvolan hoitajilla tai lääkäreillä oli käytettävänään. Tämän vuoksi perusti Väestöliitto jo kahta vuotta ennen aborttilakimme voimaan astumista erikoisen sosiaalineuvolan raskautensa vuoksi vaikeuksiin joutuneiden äitien auttamiseksi. Väestöliiton toimesta koulutettiin tähän työhön ensimmäiset sosiaalihoitajat maassamme ja myöhemmin, aborttilakimme voimaan tultua, antoi Lääkintöhallitus Väestöliiton tehtäväksi tämän neuvolatoiminnan laajentamisen ja yleisen abortintorjuntatyön suunnittelemisen ja suorittamisen.

Sosiaalineuvola pyrkii auttamaan näitä vaikeuksiin joutuneita äitejä henkisin, sosiaalisin ja lääketieteellisin keinoin. Huollollisessa mielessä neuvolan pyrkimyksenä on muuttaa potilaan tapa suhtautua vaikeuksiinsa ja opastaa häntä auttamaan itse itseään jättäytymättä passiivisena ulkopuolisen tuen varaan. Neuvolan työmuodot ovat erilaiset riippuen siitä, onko potilas naimisissa oleva tai naimaton. Yksinäisten äitien asemaa on yritetty turvata kaikin mahdollisin keinoin. Jo se, että asianomainen saa tilaisuuden vapaasti kertoa huolensa asiaa ymmärtävälle sosiaalihoitajalle, merkitsee hyvin paljon. Jos on kysymyksessä potilas, jolla ei ole minkäänlaisia mahdollisuuksia suhteen laillistamiseen - ku- 
ten useissa tapauksissa on asianlaita - ja odottavaa äitiä uhkaa työpaikan menetys tai vaikeudet ympäristön suhtautumisen vuoksi, ohjataan hänet neuvolan välityksellä ns. tukikoteihin. Tämä tukikotisysteemi on itse kehittämämme ja se on osoittautunut erittäin hyvin oloihimme sopivaksi. Tukikodeiksi on valittu ymmärtäväisiä, valistuneita perheitä, jotka osaavat oikealla tavalla suhtautua yksinäisten äitien vaikeuksiin. Näin saadaan nämä onnettomat äidit vapautumaan entisestä, kiusallisesta ympäristöstään ja samalla saadaan heidän odotusaikainen toimeentulonsa järjestetyksi, koska he tavallisimmin toimivat apuna kodin töissä ja saavat siitä palkan. Yksinäisille äideille annetaan neuvolassa myös taloudellisia neuvoja sekä selostetaan yleistä äitiyssuojelua. Harva näistä naisista on ollut tietoinen äitiysavustuksesta tai lapsen isän elatusvelvollisuudesta sekä näiden avustusten saantiin liittyvistä käytännöllisistä toimenpiteistä.

Suurin osa sosiaalineuvolan puoleen kääntyvistä on kuitenkin naimisissa olevia naisia. Heidän aborttipyyntönsä motiivit ovat suunnilleen samat kuin lapsirajoitusta pyytävien avioliittoneuvolan kävijöiden. Tämä onkin luonnollista, sillä raskaudenkeskeytys on useiden avioliitossa olevien naisten mielestä ainoa heidän tiedossaan oleva lapsirajoituksen muoto. Raskautta ei luonnollisestikaan pyritä neuvolan toimesta viemään loppuun asti hinnalla millä hyvänsä, vaan jos sosiaalisten syiden lisäksi esiintyy terveydellisiä seikkoja, jotka oikeuttavat lainmukaiseen keskeytykseen, toimitetaan potilaat asianomaiseen keskeytyssairaalaan.

Seitsemän vuoden aikana saamamme kokemukset sosiaalineuvolan toiminnasta osoittavat, että yli puolet keskeytystä anovista naisista saadaan asiantuntevan ohjauksen avulla luopumaan aborttiaikeestaan. Tätä saavutusta on nykyisissä oloissa pidettävä erittäin hyvänä. Tulosta arvosteltaessa on muistettava, että suurimman osan sosiaalineuvoloiden potilaista muodostavat peräti puutteellisissa olosuhteissa elävät, lukuisten perättäisten synnytysten rasittamat perheenäidit, joista vain noin joka viidennelle voidaan suorittaa raskaudenkeskeytys lain kirjaimen mukaisesti. Väestöliiton sosiaalineuvoloissa on tähän mennessä käynyt noin 7.000 
raskaudenkeskeytystä pyytävää potilasta. Epäilemättä olisi sosiaalineuvoloiden tarve maassamme huomattavasti suurempi, mutta niiden ylläpito tulee siksi kalliiksi ja neuvolan hoitoon pystyvää, erikoiskoulutuksen saanutta henkilökuntaa on niin rajoitetusti käytettävissä, että toistaiseksi on täytynyt tyytyä kolmeen neuvolaan- jotka tosin sijaitsevat maamme mustimmilla aborttiseuduilla, Helsingissä, Tampereella ja Turussa. Neuvoloiden toiminnan kautta on avautunut ainutlaatuinen mahdollisuus seurata abortinanojien määrää ja heidän motiivejaan suurissa kaupungeissamme. Näiden seikkojen tunteminen on taas muodostanut perus$\tan$ ennakoltaehkäisevälle abortintorjuntatyölle.

Avioliitossa esiintyvät, lääketieteellis-sosiaaliset ongelmat eivät luonnollisestikaan rajoitu vain yllämainittuihin kysymyksiin, vaikka ne muodostavatkin tällä hetkellä tärkeimmän osan niistä. Niiden, noin 17.000 potilaan ongelmat, jotka tähän mennessä ovat olleet käsiteltävinä avioliittoneuvoloissa, ovat sangen kirjavat ja moninaiset. Viimevuosien kuluessa on ollut havaittavissa potilaiston muuttumista sikäli, että syntyvyyden säännöstelynohjausta hakevat potilaat vähenevät suhteellisesti muiden syiden takia neuvolaan hakeutuvien lisääntyessä. Erään tällaisen ryhmän, jonka suuruus on nousemassa, muodostavat ne potilaat, jotka tulevat neuvolaan lapsettomuuden takia. Suomessa on epätavallisen paljon lapsettomia avioliittoja ja näistä on osa sellaisia, joita lääketiede pystyisi auttamaan, jos asianomaiset tietäisivät tulla ajoissa hakemaan apua. Lapsettomuus on suuri onnettomuus aviopuolisoille itselleen ja lisäksi lapsettomassa avioliitossa helposti syntyy ristiriitoja, jotka johtavat siihen, että juuri nämä avioliitot hyvin helposti purkautuvat ja ovat täten yhteiskunnallisesti ajatellen kielteisiä. Tyypillistä neuvolassa käyneille lapsettomuudesta kärsiville on - ehkä suomalaisen luonteelle ominainen - myöhäinen asioihin puuttuminen. Lapsettomuuteen tullaan tavallisimmin hakemaan apua vasta $6-8$ vuotta kestäneen hedelmättömän avioliittovuoden jälkeen, jolloin aviopuolisot ovat jo sivuuttaneet kolmannenkymmenennen ikävuotensa ja jolloin hoidon tulokset useimmiten ovat melko huonot. Aivan toisenlaiset tulokset saavu- 
tetaan, jos kaksi vuotta kestäneen sterilin avioliiton jälkeen voidaan suorittaa asian vaatimat tutkimukset ja hoitotoimenpiteet. Tällöin voidaan osaa potilaista vielä auttaa toiveissaan saada perillisiä ja tätä tietä pystytään aikaansaamaan onnellisia ja yhteiskunnallisesti täysipainoisia koteja.

Avioliitossa esiintyvät sukupuolielämän häiriötilat, kuien sukupuolinen kylmyys ja kyvyttömyys, muodostavat huomattavan yleisen ongelman. Näissä tapauksissa on aniharvoin kysymys elimellisestä viasta tai sairaudesta, vaan sukupuolielämän häiriötilat saavat alkunsa hermoston ja sielunelämän alalla tapahtuneista muutoksista ja reaktioista. Usein on häiriön perussyynä aviollinen ristiriita, josta potilas vain harvoin on itse tietoinen. Nämä potilaat kuuluvat kaikki neuvolan psykiatrin hoitoon ja heidän hoitamisensa vaatii usein pitkäaikaista psykoterapeuttista käsittelyä. Hoidon tulokset ovat melkein aina hyvät. Lisäksi paljastuvat tässä yhteydessä avioliitossa vallitsevat jännitystilat ja ristiriidat, joiden laukaiseminen muodostuu onneksi koko kodille ja perheelle.

Olen ylläolevassa pyrkinyt esittämään huomioita vain eräiltä tärkeimmiltä Väestöliiton kansanterveystoiminnan työsaroilta. Lääketieteellinen neuvonta ja ohjaus muodostaa luonnollisesti vain osan niistä väestöpoliittisista toimenpiteistä, joilla valveutunut yhteiskunta pyrkii turvaamaan väestön kasvun ja laadullisen parantumisen. Se on tässä tehtävässä kuitenkin monessa suhteessa avainasemassa, josta johtuen sen tarjoama apu olisi saatava kaikkien kansalaisten ulottuville. 